\title{
The 'Little Ice Age' in the Himalaya: A review of glacier advance driven by Northern Hemisphere temperature change
}

\author{
Ann V Rowan
}

\begin{abstract}
Northern Hemisphere cooling between 1400 and 1900 in the Common Era (CE) resulted in the expansion of glaciers during a period known as the 'Little Ice Age' (LIA). Early investigation of recent advances of Himalayan glaciers assumed that these events were synchronous with LIA advances identified in Europe, based on the appearance and position of moraines and without numerical age control. However, applications of Quaternary dating techniques such as terrestrial cosmogenic nuclide dating have allowed researchers to determine numerical ages for these young moraines and clarify when glacial maxima occurred. This paper reviews geochronological evidence for the last advance of glaciers in the Himalaya. The 66 ages younger than 2000 years (0-2000 CE) calculated from I38 samples collected from glacial landforms demonstrate that peak moraine building occurred between I300 and I600 $\mathrm{CE}$, slightly earlier than the coldest period of Northern Hemisphere air temperatures. The timing of LIA advances varied spatially, likely influenced by variations in topography and meteorology across and along the mountain range. Palaeoclimate proxies indicate cooling air temperatures from I $300 \mathrm{CE}$ leading to a southward shift in the Asian monsoon, increased Westerly winter precipitation and generally wetter conditions across the range around I400 and $1800 \mathrm{CE}$. The last advance of glaciers in the Himalaya during a period of variable climate resulted from cold Northern Hemisphere air temperatures and was sustained by increased snowfall as atmospheric circulation reorganised in response to cooling during the LIA.
\end{abstract}

\section{Keywords}

Asia, glacier change, Himalaya, India, late Quaternary, Nepal

Received 21 February 2016; revised manuscript accepted 16 May 2016

\section{Introduction}

The Himalaya contain the largest volume of glacier ice outside of the Arctic and Antarctic (Bolch et al., 2012). However, the drivers of recent glacier change in the Himalaya are not well constrained, and so relatively little is known about how these glaciers respond to Northern Hemisphere climate change. The 'Little Ice Age' (LIA) was a short-lived period of widespread cooling in the Northern Hemisphere characterised by mean annual temperature change of about $-0.5^{\circ} \mathrm{C}$, with lowest temperatures between 1400 and 1700 in the Common Era (CE) (Mann et al., 2009; Wilson et al., 2016) (Figure 1). The LIA represents the last advance of glaciers in Western Europe (Holzhauser et al., 2005), Iceland (Larsen et al., 2013) and North America (Luckman, 2000) (Figure 1). Glaciers in the European Alps advanced three or four times during the LIA (e.g. Schimmelpfennig et al., 2014). Advances of the largest glaciers in the Western Alps appear to have been synchronous (Holzhauser et al., 2005), but out of phase with two advances in Iceland (Larsen et al., 2013). The term 'LIA' is also used to describe the last advance of glaciers elsewhere in the world, for example, the Southern Alps of New Zealand (Lorrey et al., 2013) and the Himalaya (Kayastha and Harrison, 2008; Kick, 1989).

Techniques such as radiocarbon $\left({ }^{14} \mathrm{C}\right)$ dating and terrestrial cosmogenic nuclide (TCN) dating can be used to elucidate the timing of Holocene moraine formation and infer the drivers of glacier change (e.g. Schimmelpfennig et al., 2012). Glaciers in the middle and low latitudes are particularly sensitive to climate change (Oerlemans et al., 1998), and glacier change is a potentially valuable palaeoclimate proxy for the Himalaya, as many glaciers exist across a wide range of latitudes and altitudes. Only few of the Holocene moraines created by Himalayan glaciers have been dated, although sufficient ages do exist to infer when and why glaciers have changed through the Quaternary (e.g. Dortch et al., 2013; Murari et al., 2014; Owen and Dortch, 2014; Owen et al., 2009). The relatively small numbers of ages produced for LIA moraines by individual studies, and the reliance of some of these ages on applications of these dating techniques that have since been updated, means that some of these data must be treated cautiously. Bringing together all these previous studies creates a much larger and potentially more informative dataset. The reliability of each age was evaluated based on the approach used to collect samples and analyse the landform ages. This paper examines the geological evidence for the last advance of glaciers

Department of Geography, University of Sheffield, UK

\section{Corresponding author:}

Ann V Rowan, Department of Geography, University of Sheffield, Winter Street, Sheffield SIO 2TN, UK.

Email: a.rowan@sheffield.ac.uk 


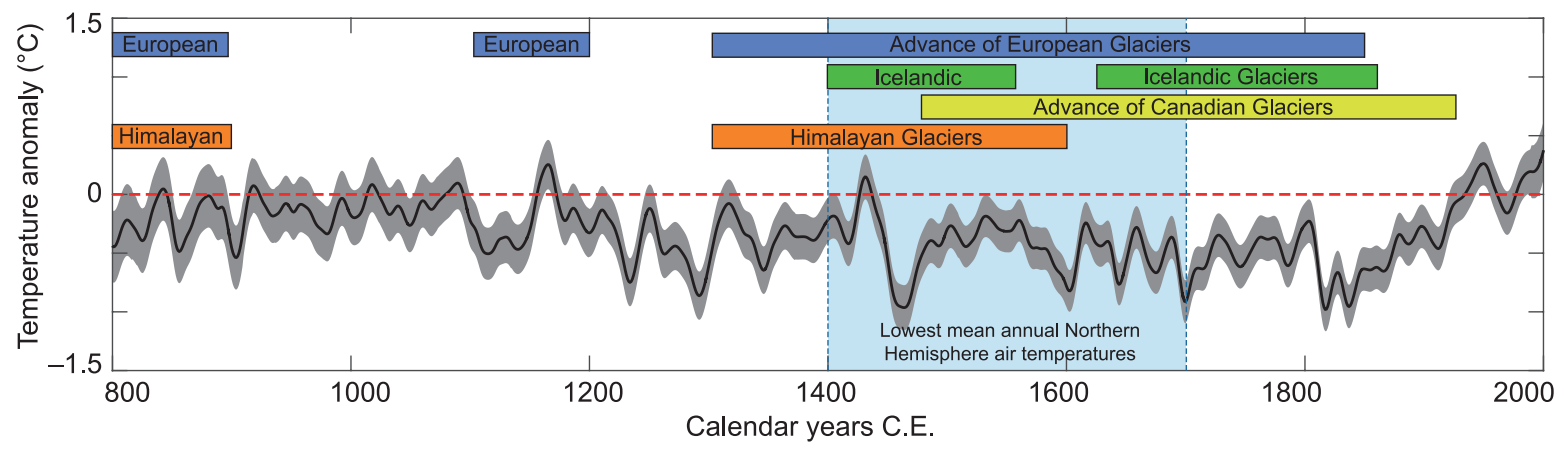

Figure I. Northern Hemisphere May-August temperature anomaly for 800-2000 CE with respect to the period I96I-I990 CE produced from tree ring records filtered with a 20 -year spline (black line) with $2 \sigma$ uncertainties (grey shading) (Wilson et al., 2016). The vertical bar shows the period of lowest mean annual air temperatures. The bars above the black line show the timing of LIA glacier advances in the European Alps (Holzhauser et al., 2005), Iceland (Larsen et al., 2013) and North America (Luckman, 2000), and the timing of the LIA in the Himalaya inferred from this analysis of moraine ages.

across the Himalaya to discover the timing relative to Northern Hemisphere climate change and determine the controls on glacier change. Gaps in understanding of the timing of late-Holocene advances are identified to guide future studies of the drivers of recent glacier change in the Himalaya.

\section{Glaciers in the Himalaya}

The Himalaya are a range of high mountains extending from northern Pakistan through northern India, Nepal, Bhutan and China spanning $2400 \mathrm{~km}$ across latitudes from $26^{\circ} \mathrm{N}$ to $37^{\circ} \mathrm{N}$ (Figure 2). The Himalaya contain a glacierised area of around $22,800 \mathrm{~km}^{2}$ (Bolch et al., 2012) composed of over 40,000 individual glaciers (GLIMS, National Snow and Ice Data Center, 2005). The Himalayan mountain range is divided into three regions - the Western Himalaya, the Central Himalaya and the Eastern Himalaya (Bolch et al., 2012). The Eastern Himalaya comprises Bhutan, the Sikkim and Arunachal Pradesh regions of India bounded by Tsangpo Gorge to the east, and part of Tibet directly to the north as far as the Brahmaputra River. The Central Himalaya includes Nepal, Uttarakhand in northern India and part of Tibet directly to the north. The Western Himalaya contains the Himachal Pradesh and Jammu regions of India, and Kashmir, extending into the easternmost part of Pakistan and Tibet to the east. Glaciers on the Tibetan Plateau are excluded from this review as their behaviour is controlled by markedly different topography and climatic regimes to those glaciers in the high mountains. The focus of this paper is on glaciers in the Himalaya, but glaciers in the Karakoram range adjacent to the Western Himalaya are included as some glacial geochronological data exist here. The Karakoram is mostly within northern Pakistan and contains the Gilgit-Baltistan region and part of Tibet to the east (Figure 2).

Mean glacier elevations, which can be used as a proxy for Equilibrium Line Altitude (ELA), rise from about $5200 \mathrm{~m}$ in the Western Himalaya to about $5600 \mathrm{~m}$ a.s.l. in the Eastern Himalaya (Bolch et al., 2012). Glaciers in the Himalaya have a generally negative net mass balance and are shrinking at rates that have accelerated since the 1990s (Kääb et al., 2012). Many of the large recent moraines in the Himalaya were built by debris-covered glaciers. These debris-covered glaciers have thick insulating layers of supraglacial rock debris and lose most mass by surface lowering rather than terminus recession (Benn et al., 2012; Rowan et al., 2015). As a result, many Himalayan glaciers remain close to their LIA extents at the present day, which may have misled early explorer-scientists in interpreting the state of these glaciers (as summarised by Grove, 2004).

The timing of LIA glacier advances in the Himalaya was historically inferred based on the visual similarity between recent moraines in the Himalaya and the European Alps (Grove, 2004).
Some of these inferences have entered the glaciological literature without supporting geochronological data, leading researchers to debate the possibility of correlations between glacier advances in the Himalaya and Europe (e.g. Iwata, 1976). Historical records of glacier change in the Himalaya are extremely scarce. The conclusion that most glaciers in the Himalaya have been receding since $1850 \mathrm{CE}$ is based on observations made in the early 19th Century and without the availability of geochronological data to constrain the timing of advance or recession (as summarised by Mayewski and Jeschke, 1979). The limitations of these historical records of glacier change in the Himalaya are summarised by Kick (1989), who noted an apparently large variation in the timing of the onset of glacier recession in the Himalaya compared with the European Alps. Kick (1989) estimated the onset of recession in the Himalaya as 'anywhere between the beginning of the $19^{\text {th }}$ Century and the beginning of the $20^{\text {th }}$ [Century]'. This interpretation is based on observations made at that time based on the assumption that glaciers had only recently reached their observed positions.

More recently, ages for some Holocene moraines in the Himalaya were produced as part of larger studies looking at the timing of advances over much longer periods (e.g. Dortch et al., 2013; Owen and Dortch, 2014; Owen et al., 2009). The production of numerical ages removes the dependence on historical records and visual interpretations of glacier mass balance to infer glacier change, and allows the timing of the LIA to be constrained across wider geographical areas by comparison of data from different sites (e.g. Dortch et al., 2013; Murari et al., 2014; Owen and Dortch, 2014). Two sets of recent moraines occur in front of several Himalayan glaciers, such as Khumbu Glacier in Nepal, Pasu Glacier in Pakistan and Batal Glacier in Lahul, and are assigned to the LIA and a preceding late-Holocene (sometimes called 'Neoglacial') advance (Derbyshire and Owen, 1997). These two moraines are likely to represent an initial late-Holocene maximum followed by subsequent thickening of the glacier during the LIA constrained by this preexisting moraine to produce another crest inside the older one (Owen et al., 1996).

\section{Numerical dating techniques applied to glacial landforms}

Numerical ages are assigned to glacial landforms in the Himalaya using terrestrial cosmogenic nuclide (TCN) dating, optically stimulated luminescence (OSL) dating and radiocarbon $\left({ }^{14} \mathrm{C}\right)$ dating. All of these techniques can be applied to produce ages with a resolution of decades to centuries for landforms generated during the Holocene period. For Himalayan glacial landforms that have been dated to the late-Holocene, the majority of ages have been produced using ${ }^{14} \mathrm{C}$ and $\mathrm{TCN}$, with only one age resulting from OSL dating. Each technique and the associated measurement uncertainties are reviewed here as applied to Himalayan glacial 







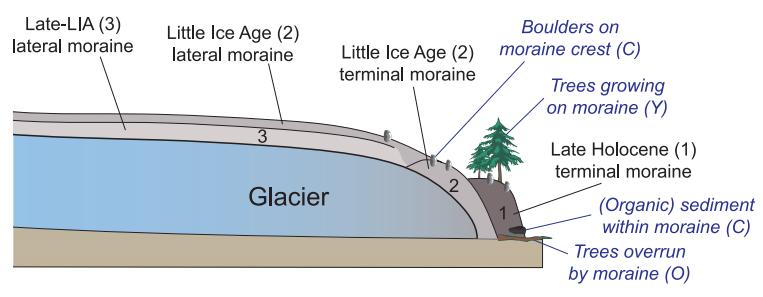

Figure 3. How ages produced from different materials at individual sites relate to glacier behaviour and glacier evolution where two or three moraines are present. In relation to glacier maxima, the sample age is $(\mathrm{Y})$ younger, $(\mathrm{C})$ contemporary or $(\mathrm{O})$ older, depending on the type and location of the material sampled.

landforms, and uncertainty resulting from the geomorphological context of the material sampled for dating is summarised.

Radiocarbon dating. Radiocarbon $\left({ }^{14} \mathrm{C}\right)$ dating measures the radioactive decay of ${ }^{14} \mathrm{C}$ compared with stable carbon isotopes to determine the age of a sample in ${ }^{14} \mathrm{C}$ years before present. This isotopic age must be calibrated against material of known age to convert the measurement into calendar years using the international calibration curve, called 'IntCal13' (Reimer et al., 2013). The start of the LIA is poorly resolved across a plateau in the ${ }^{14} \mathrm{C}$ calibration curve until around $1650 \mathrm{CE}$ (Reimer et al., 2013). ${ }^{14} \mathrm{C}$ dating relies on the presence of organic carbon, particularly in the form of terrestrial plant material, in the landform under investigation for dating, which is generally scarce within glacial sediments. As glacial landforms such as moraines generally contain little organic material, the sample for ${ }^{14} \mathrm{C}$ dating is typically taken from deposits associated with rather than incorporated into glacial sediments, for example, within an overlying soil or lacustrine deposit (Figure 3). The majority of ${ }^{14} \mathrm{C}$ ages (30 of 37 ages) produced for glacial landforms in the Himalaya are the result of sample collection and laboratory analyses undertaken between 1960 and 1990 $\mathrm{CE}$ when laboratory techniques for measurement of these isotopes were less precise than at present. More recent studies have measured ${ }^{14} \mathrm{C}$ using accelerator mass spectrometry to give greater precision in their results. In every case, only one sample was used to produce each age, that is, each age was not calculated from a set of samples to give a representative age distribution. Of these ages, 13 were produced by analysis of wood or charcoal, and the remainder from soils.

TCN dating. Terrestrial Cosmogenic Nuclide (TCN) dating measures the isotopic ratios resulting from the radioactive decay within rocks of the products formed by bombardment with cosmogenic nuclides. TCN dating of glacial landforms frequently uses ${ }^{10} \mathrm{Be}$ extracted from quartz within individual boulders (e.g. Owen et al., 2009), although ${ }^{3} \mathrm{He}$ from garnets was used for moraines in the Ganesh Himal (Gayer et al., 2006). TCN dating is applied to measure the exposure age of a moraine boulder by calculating the content of the isotope in question, calibration of the production rate of this isotope based on cosmogenic isotopic fluxes and topographic shielding (Heyman et al., 2016), and an estimate of the amount of erosion that the surface has undergone. Isotopic measurement uncertainties are generally low as accelerator mass spectrometry is used to make precise measurements. Ages produced using TCN dating are often calculated using statistical analysis of a population of dates for several samples collected from an individual moraine, rather than only one sample per landform. The 28 ages produced using TCN dating for moraines in the Himalaya are the result of analysis of 100 individual samples.

OSL dating. Optically Stimulated Luminescence (OSL) dating measures the timing of deposition of sediments by measuring the radiation dose produced from background radiation that has accumulated within quartz grains of the sediment itself. An advantage of OSL dating is that unlike ${ }^{14} \mathrm{C}$ and TCN dating, this technique does not require calibration against a long-term isotopic production rate. The OSL signal is reset by sunlight, and so this technique relies on the assumption that sediments were sufficiently exposed to light during transport prior to deposition to reset the measured signal. The age of a sediment is determined by dividing the measured total radiation dose by the estimated annual dose rate. Although OSL dating has been used to date Quaternary moraine sequences in the Himalaya, only one of the ages produced relates to LIA deposits, which is measured from one sample collected from the moraine of Lhotse Glacier in the Central Himalaya (Richards et al., 2000).

Geomorphological uncertainties in geochronological sampling. Measurement uncertainties are generally low (less than 10\%) for isotopic dating methods, but uncertainties in measured ages also arise from the choice of site and material sampled for dating. The strength of geochronological data relies on careful interpretation of the geomorphological setting of the sampled material, understanding of the processes that created the landforms under investigation and the analysis of multiple samples from each landform. All the geochronological techniques described here produce ages which have differing temporal relationships with glacier change (Figure 3 ). ${ }^{14} \mathrm{C}$ dating measures the age since death of organic material collected from ancient trees or soils which either pre- or post-date glacier advance. Preserved trees and soils may be found underlying moraines, where they are assumed to be older than the advance that built these moraines, or trees may grow on the surface of moraines and post-date advances (Figure 3). TCN exposure ages from boulders contained within moraines date the amount of time for which the boulder has been exposed at the topographic surface, which is assumed to be coincident to the peak of moraine formation if the boulder is at the moraine crest. However, geomorphological processes degrade moraines after their formation and can influence the distribution of boulder ages in a manner that may not be apparent when samples are collected (Applegate et al., 2010; Kirkbride and Winkler, 2012). The collection and analysis of samples from multiple boulders within an individual moraine can reduce the likelihood of biasing the age results from collecting one sample that may be anomalously 'old' or 'young'. OSL dating measures the amount of time since deposition of the sediment and therefore also requires interpretation of what the sediment in question represents. In the case of the OSL age from the terminal moraine of Lhotse Glacier, this sample was collected from a sand lens enclosed within a moraine and therefore was deposited earlier than the boulders on the moraine crest.

\section{Glacier advances in the Himalaya since the start of the Common Era}

This paper reviews 66 ages from moraines and closely associated landforms indicating glacier advance in the Himalaya since the start of the Common Era ( $0 \mathrm{CE}$ ), produced from 138 samples. The moraine ages were produced using TCN dating (number of ages $(n)=28)$, OSL dating $(n=1)$ and ${ }^{14} \mathrm{C}$ dating $(n=37)$ (Table 1 and Figure 4). All ages are given in calendar years CE. ${ }^{14} \mathrm{C}$ ages were recalibrated using the OxCal program with the IntCal 13 calibration curve (Reimer et al., 2013), taking the stated ${ }^{14} \mathrm{C}$ cal. $\mathrm{yr} \mathrm{BP}$ age and the associated error to give the age of the sample in calendar years CE (Table 2). All uncertainties are given to $1 \sigma$, and the mean uncertainty across all ages presented was $16 \%$. Where the authors did not give uncertainties for their ages, these are indicated in Table 1 and assumed to be $10 \%$ of the stated age so that these ages could be included in the compiled dataset by 


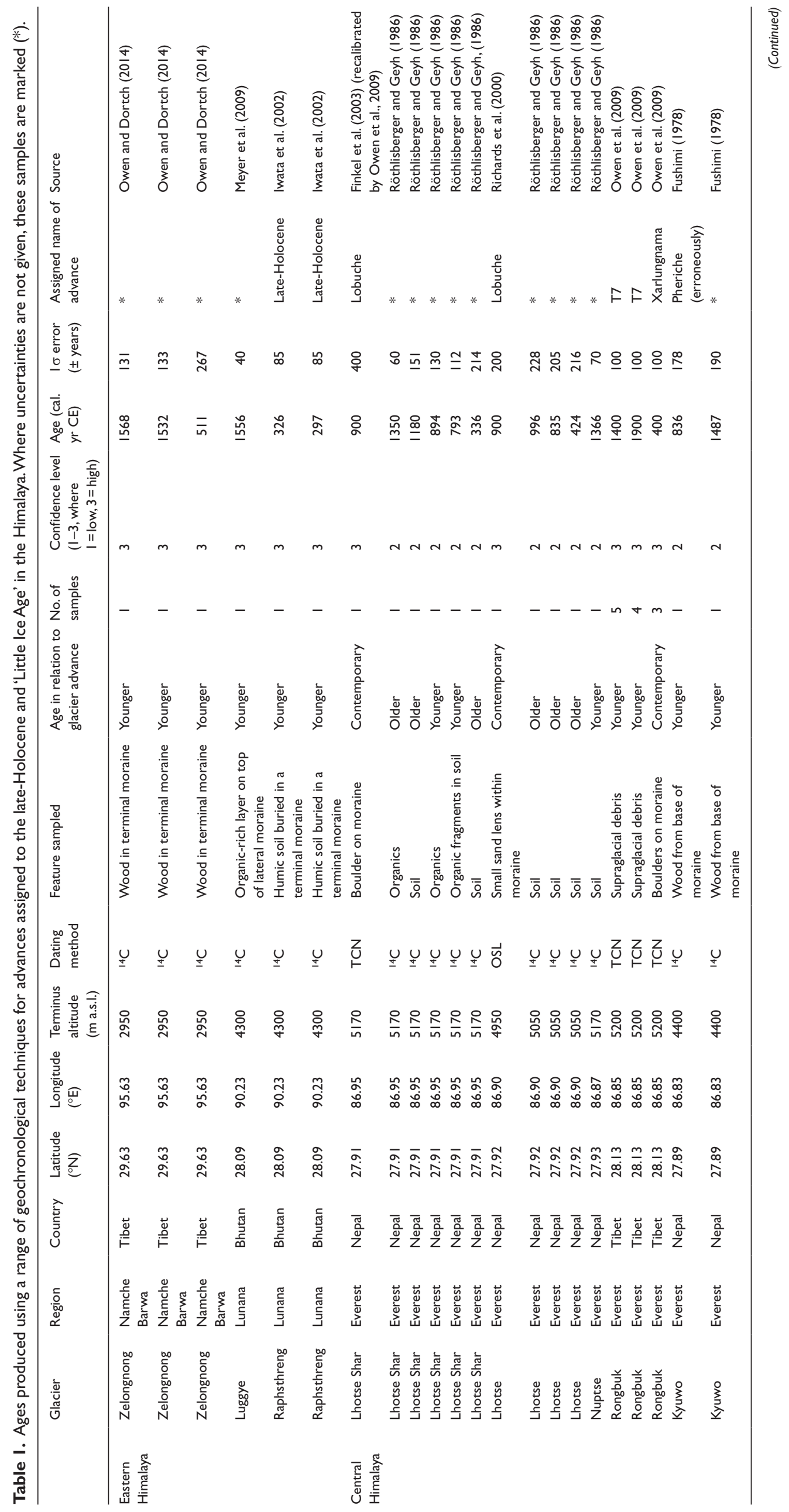




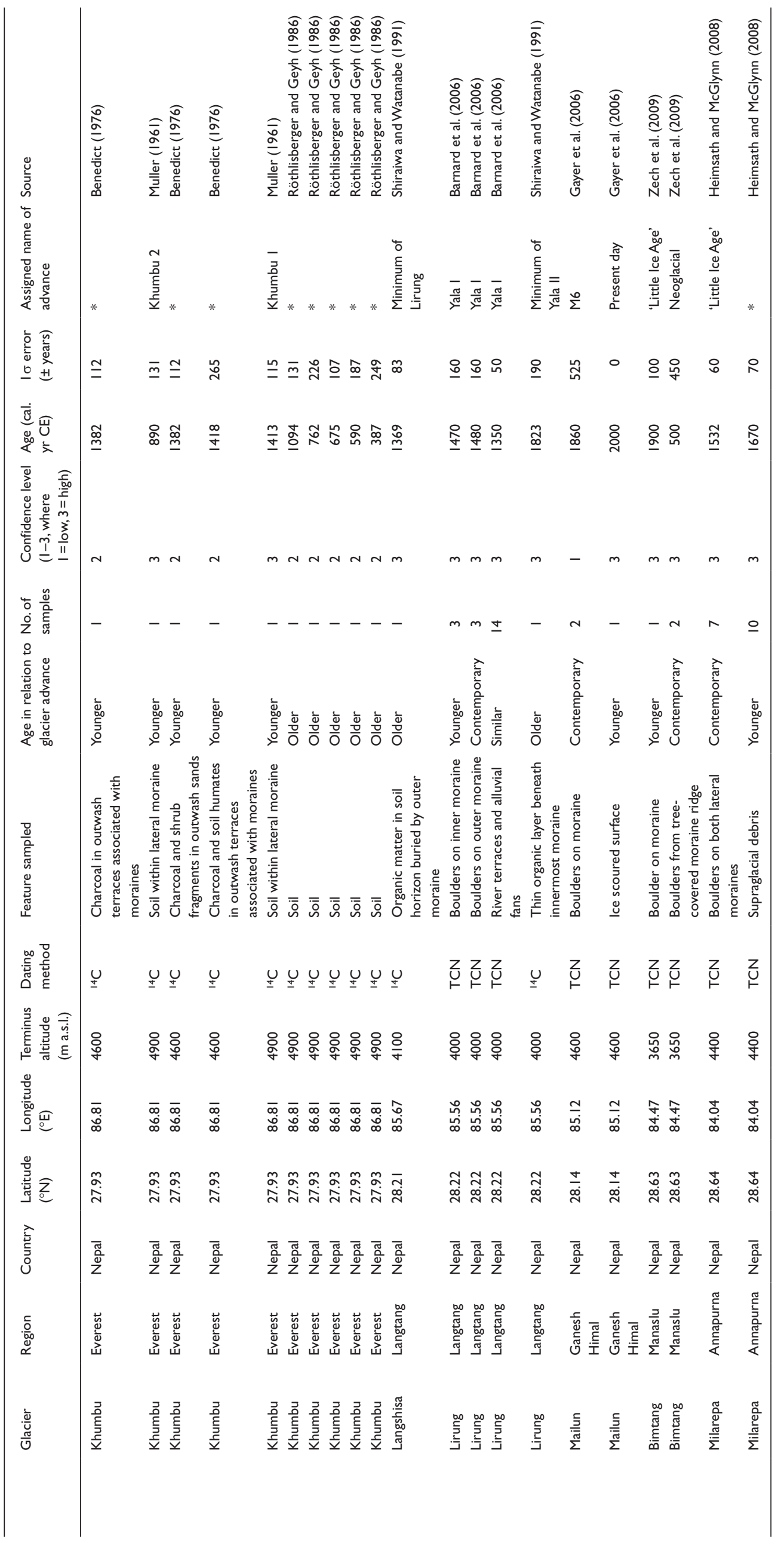




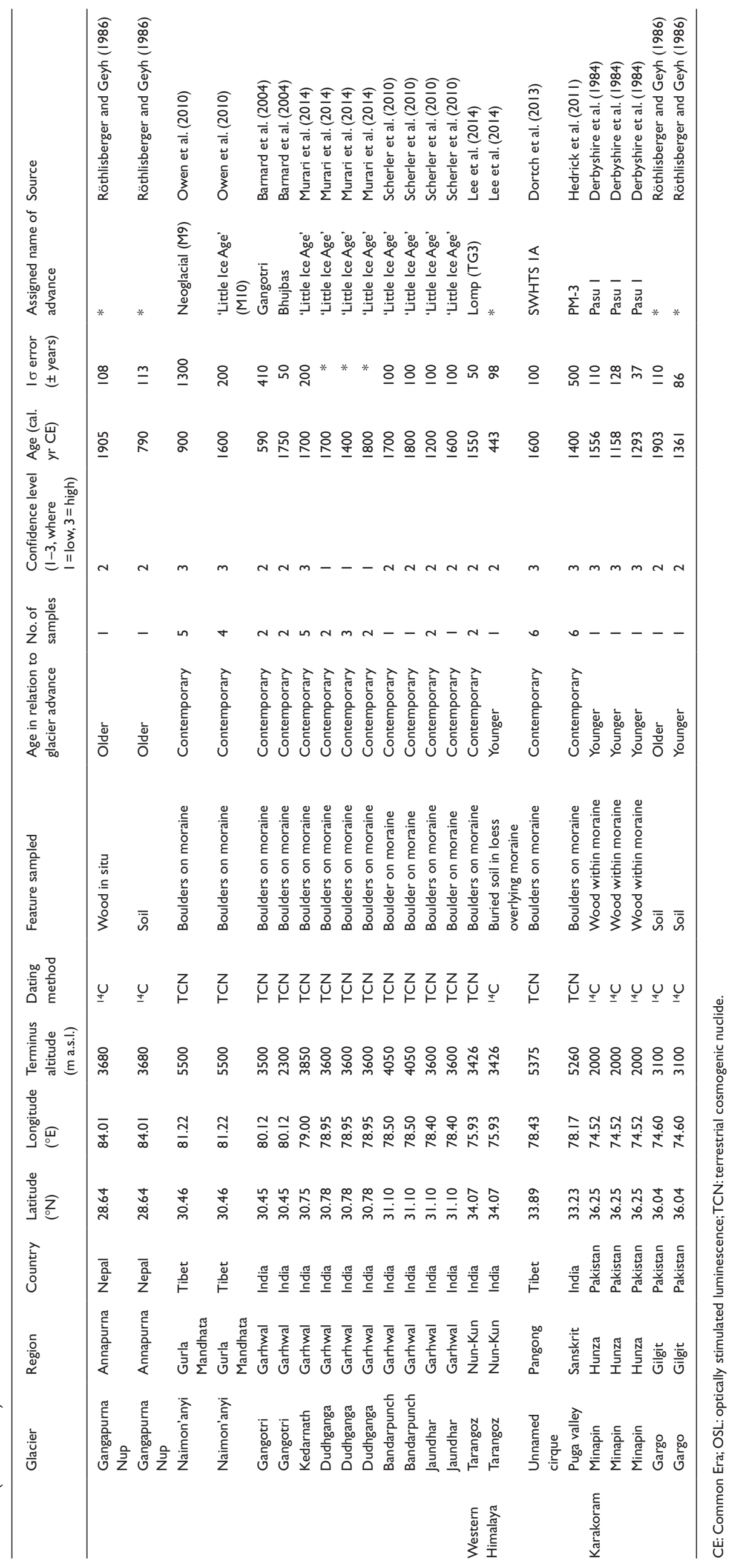



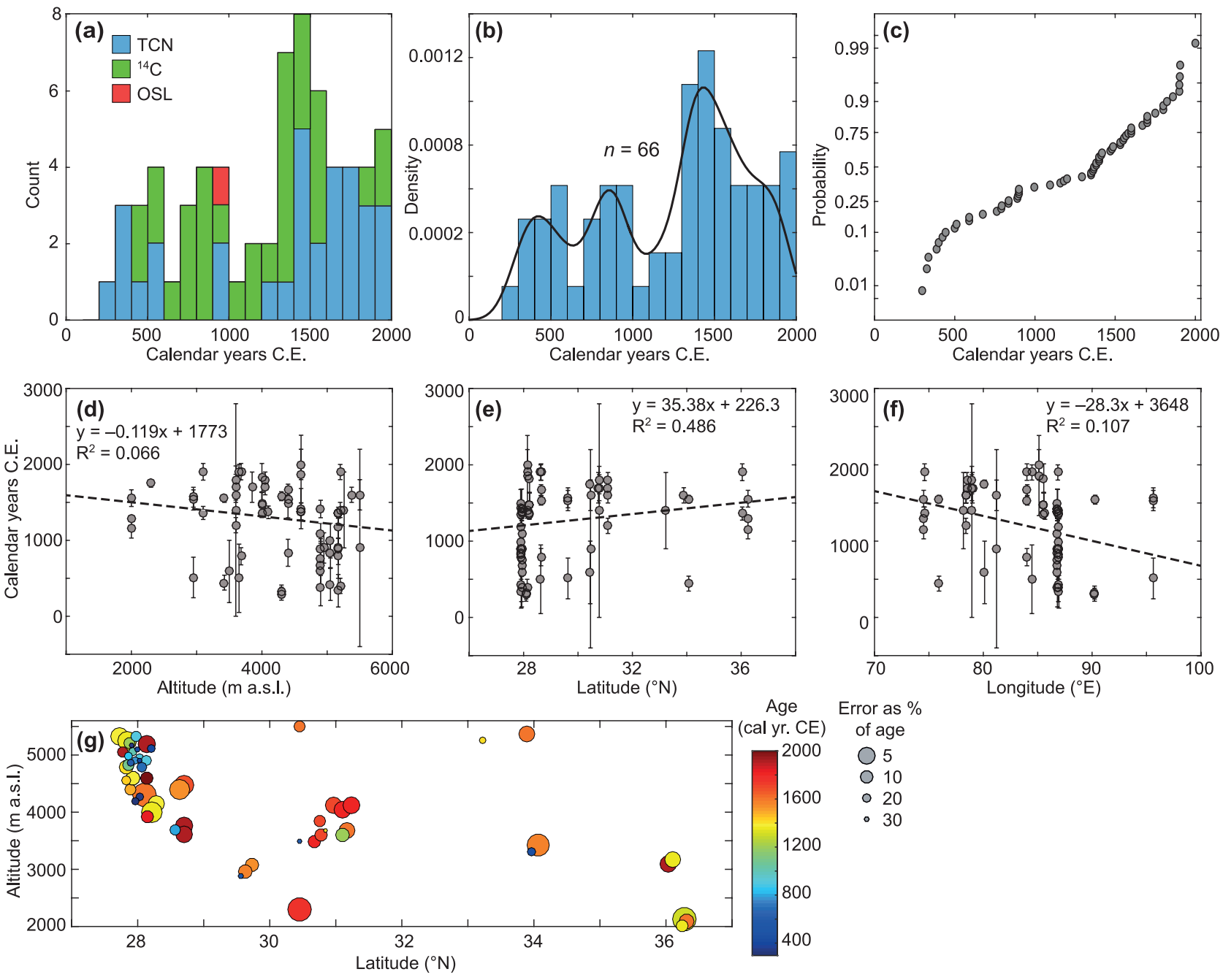

Figure 4. The distribution of moraine ages assigned to glacier advances during the Common Era in the Himalaya, shown as (a) a histogram count of ages with each geochronological technique represented by different colours, (b) probability density plot of ages and (c) cumulative probability of age distribution. All moraine ages plotted against (d) altitude, (e) latitude and (f) longitude, where the linear regression is weighted by the error associated with each age. (g) The distribution of all moraine ages by latitude and altitude, where the colour of the point gives the age and size of the point indicates the uncertainty associated with the age (larger points have smaller uncertainties).

representing a conservative estimate similar to the mean uncertainty. A confidence level was assigned to each age to indicate the reliability of the stated age based on the method used, the number of samples collected and the geomorphological context of the sampling locations (Table 1). All samples without a stated uncertainty were given the lowest confidence level rating of 1. Geochronological data from recent moraines in the Himalaya are discussed below in the context of the region in which the glaciers are located. Data from the Eastern and Western Himalaya and Karakoram regions are few compared with those from the Central Himalaya (Figure 2).

In some cases, more than one sample was dated to provide an age for a particular landform, giving greater confidence in the result. Applications of TCN generally use multiple samples to generate an age distribution for a particular landform, giving one representative age that captures some of the geomorphological uncertainties in the landform age. The number of samples used to calculate each age is given in Table 1, and only the one resulting age is used in calculating the timing of regional glacier change. Conversely, applications of ${ }^{14} \mathrm{C}$ tend to use only one sample per landform, and where more than one sample is collected for the same glacier, these are often from different materials and not in close proximity, or the sample location is difficult to interpret from the information given in the publication in question.
Therefore, ${ }^{14} \mathrm{C}$ ages are presented as given by the original authors and not combined based on sampling location. The potential for bias in the resulting compiled age distribution towards the relatively greater number of ${ }^{14} \mathrm{C}$ ages is accounted for, as for those landforms where only one sample was dated the uncertainty associated with these ages is generally higher.

\section{Eastern Himalaya}

The Raphsthreng moraines in the Lunana valley in Bhutan were dated to $241-411 \mathrm{CE}$ and $43-212 \mathrm{CE}$ using ${ }^{14} \mathrm{C}$, and assigned to the LIA (Iwata et al., 2002). However, these samples are for moraines formed by two different glaciers, and although the authors assign both ages to the LIA, they appear to have been taken from nearby but older moraines. These two sets of moraines are given an age range of $3 \mathrm{ka}$ to $1900 \mathrm{CE}$, but this minimum age is an assumption about the glacial history and has not been dated (Iwata et al., 2002). Further east, two ${ }^{14} \mathrm{C}$ ages from wood in the terminal moraines of Zelongnong Glacier in Namche Barwa in Tibet indicate a last advance around $1450 \mathrm{CE}$ preceded by an earlier advance around $500 \mathrm{CE}$ (Owen and Dortch, 2014). The age of the youngest moraine of Zelongnong Glacier is 1399-1665 CE which agrees with the age of 1516-1596 CE for the youngest moraine of Luggye Glacier in the Lunana valley in Bhutan (Meyer et al., 2009). 


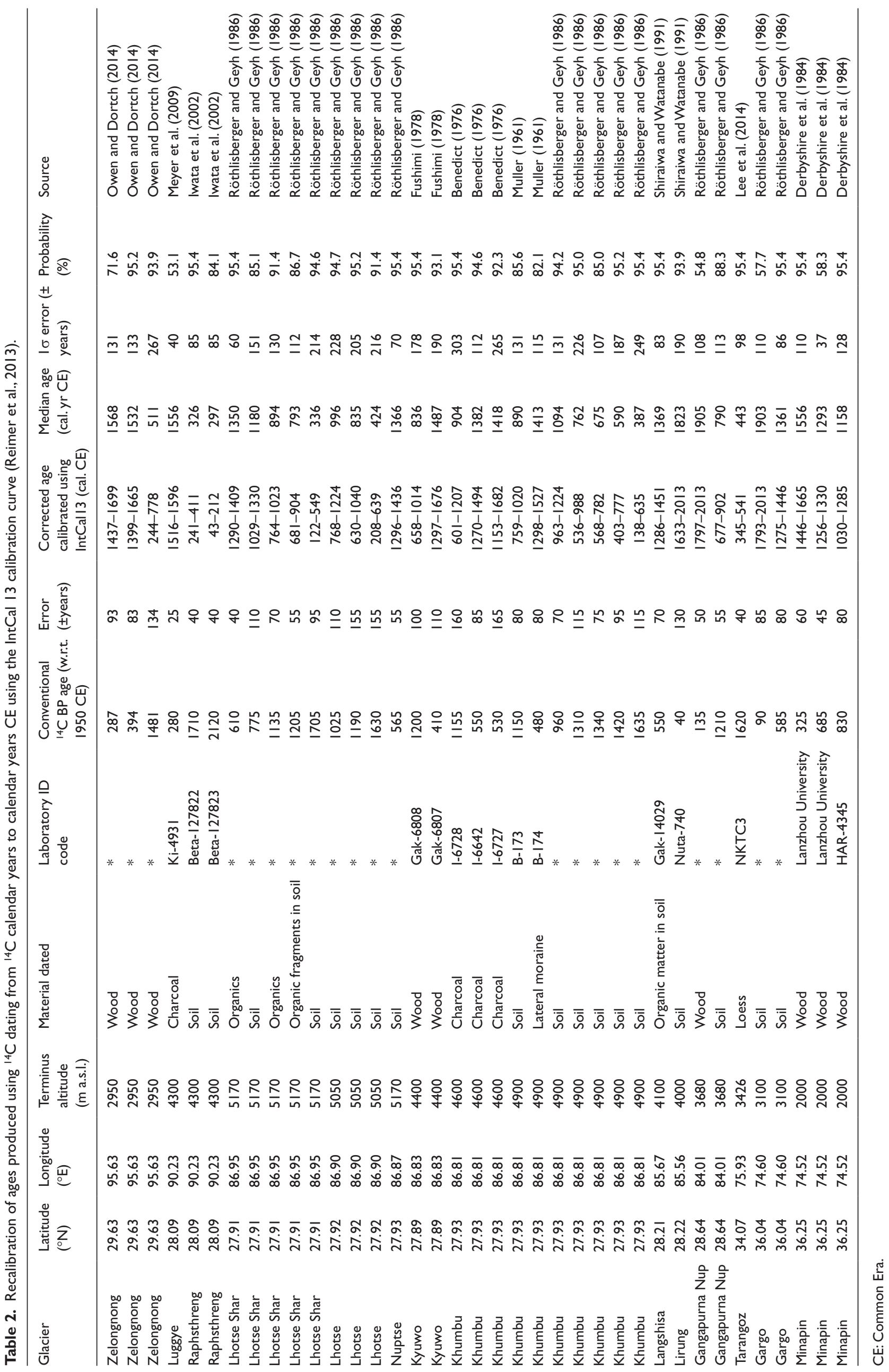



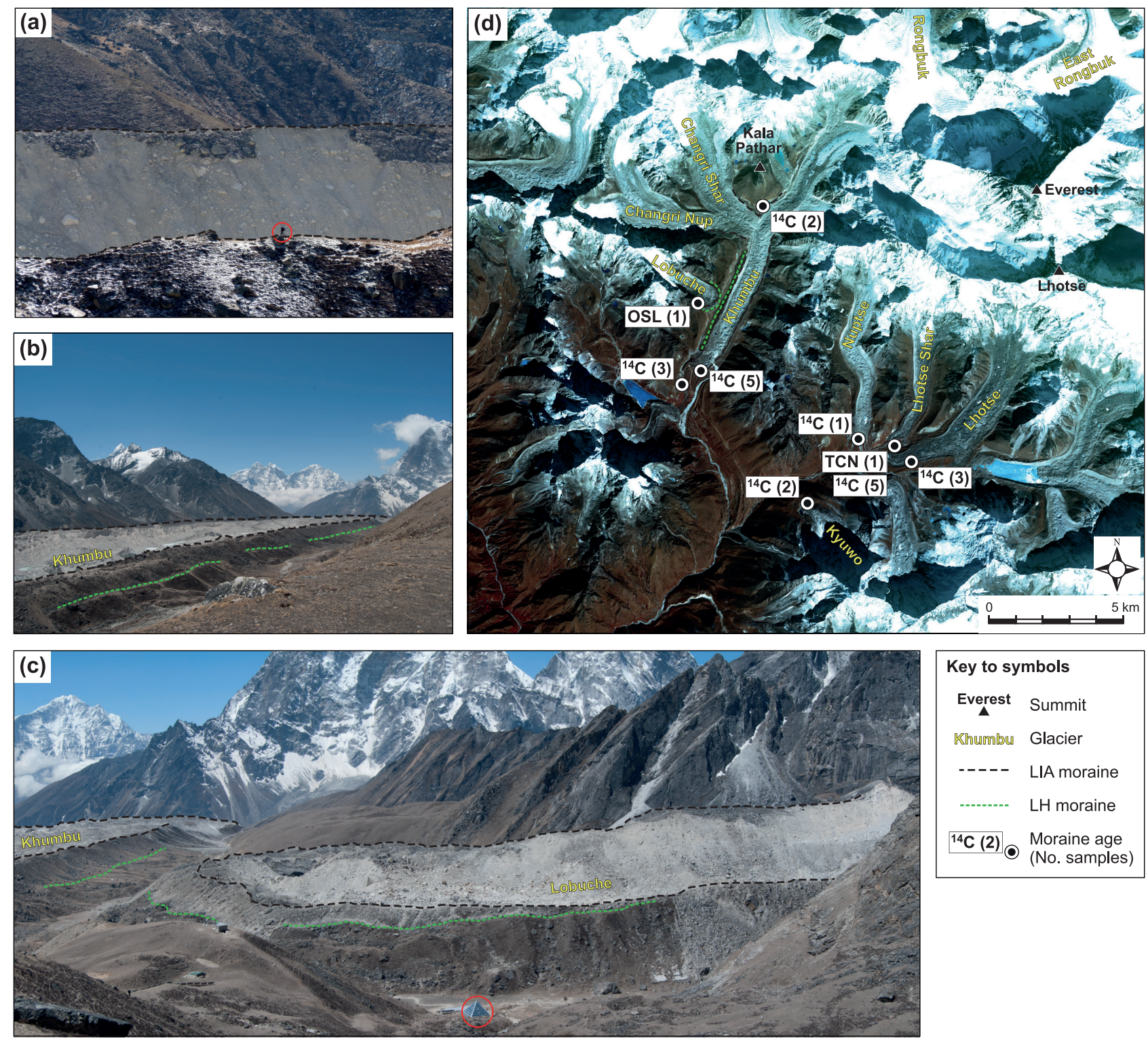

Figure 5. The late-Holocene (LH) and 'Little Ice Age' (LIA) moraines of Khumbu and Lobuche Glaciers in the Everest region of Nepal, showing (a) the left-lateral and right-lateral LIA moraine crests of Khumbu Glacier (note person circled for scale); (b) left-lateral and right-lateral LIA and right-lateral late-Holocene moraine crests of Khumbu Glacier, seen from a similar viewpoint to (a); (c) lateral and terminal LIA moraines and lateral late-Holocene moraines of Khumbu and Lobuche Glaciers (note Pyramid atmospheric research station circled for scale). (d) Summary map of ages produced for moraines the Everest region, showing the location of samples, the geochronological method used and the number of individual samples represented by each age. Ages are presented in Table I and taken from studies by Finkel et al. (2003) and Owen et al. (2009) using TCN; Richards et al. (2000) using OSL; Muller (196I), Benedict (1976), Fushimi (1978) and Röthlisberger and Geyh (1986) using ${ }^{14} \mathrm{C}$.

\section{Central Himalaya}

The Central Himalaya has more glacial geochronological data than other regions; 51 ages have been produced for glacial or associated landforms formed since $0 \mathrm{CE}$. In particular, the Everest region in Nepal and Tibet contains some of the best-studied moraine sequences because of relatively good access and the history of exploration here.

The Everest region. The Everest region includes the Khumbu Himal and Rongbuk Glaciers for which detailed late Quaternary geochronologies exist (e.g. Owen et al., 2009; Richards et al., 2000). Recent moraines in the Imja valley immediately to the south of Mt Everest were identified for the Nuptse, Lhotse, Lhotse Shar, Ama Dablam, Chukung, Kyuwo and Raiha Glaciers (Iwata, 1976). One age has been produced using OSL dating for a sand lens in the Lhotse Glacier terminal moraine of $900 \pm 200 \mathrm{CE}$ (Richards et al., 2000) and is supported by three similar ${ }^{14} \mathrm{C}$ ages for this moraine and five from that of the neighbouring Lhotse
Shar Glacier (Röthlisberger and Geyh, 1986). The moraine of Kyuwo Glacier was dated using ${ }^{14} \mathrm{C}$ to $1014-658 \mathrm{CE}$ (Fushimi, 1978), and although this moraine was assigned by Fushimi to the Pheriche advance (equivalent to the Last Glacial Maximum (LGM) around $21 \mathrm{ka}$ ), this age is likely to instead represent the late-Holocene advance because of the morphological similarity with the moraines dated by Owen et al. (2009).

Two sets of lateral and terminal moraines are located immediately outboard of the present-day margin of Khumbu Glacier (Figure 5). These moraines represent the last Holocene advances and have previously been grouped together as one event in the absence of geochronological data (Iwata, 1976). The outmost subdued lateral moraine ridge of large glaciers in the Khumbu Himal is assigned to a late-Holocene advance (Richards et al., 2000). The late-Holocene advance was called the Lobuche advance and dated to $900 \pm 400 \mathrm{CE}$ using TCN dating of one sample from the moraine of Lhotse Shar Glacier (Owen et al., 2009) and 900 \pm 200 CE using OSL of one sample from neighbouring Lhotse Glacier (Richards 
et al., 2000). The Lobuche advance of Khumbu Glacier was also dated to $601-1207 \mathrm{CE}$ using ${ }^{14} \mathrm{C}$ applied to a soil sample collected from an outwash terrace at the base of the outer terminal moraine below Dugla village (Benedict, 1976), and five samples from nearby soil profiles gave ages around $700 \mathrm{CE}$ (Röthlisberger and Geyh, 1986). The recent Xarlungnama moraines formed by Rongbuk Glacier on the northern side of Mt Everest were dated to $400 \pm 100 \mathrm{CE}$ from TCN dating of three samples, which is broadly synchronous with the late-Holocene advance of glaciers in the Khumbu Himal (Owen et al., 2009).

Inboard of the late-Holocene moraine formed by Khumbu Glacier, a soil profile at Gorak Shep lake that lies between moraine sets, was dated using ${ }^{14} \mathrm{C}$ to $759-1020 \mathrm{CE}$ and 1298 $1527 \mathrm{CE}$ (Muller, 1961). Two ${ }^{14} \mathrm{C}$ ages from samples taken from an outwash terrace below Dugla village directly above that from which the older Dugla sample was collected gave ages of 1270$1494 \mathrm{CE}$ and 1153-1682 CE (Benedict, 1976). The most recent moraines formed by Kyuwo Glacier were dated using ${ }^{14} \mathrm{C}$ as 1297-1676 CE (Fushimi, 1978). These six moraine ages falling around $1500 \mathrm{CE}$ are all assigned to the LIA (Benedict, 1976; Fushimi, 1978; Muller, 1961). Although younger moraines were identified by Owen et al. (2009) at the Rongbuk Glacier inboard of the Xarlungnama moraines, these have not been dated.

Western and Central Nepal. Glaciers in the Langtang region of Nepal to the west of the Everest region have mean terminus altitudes of around $4000 \mathrm{~m}$, lower than those in the Everest region of 4900-5200 m (Table 1). In the Langtang catchment, two advances named Yala I and Yala II were preceded by the Lirung advance. The minimum age of the Lirung advance based on a ${ }^{14} \mathrm{C}$ date from the moraines formed by Langshisa Glacier is 1286-1527 CE (Shiraiwa and Watanabe, 1991). TCN dating of 14 samples collected from proglacial river terraces and alluvial fans places the age of Yala I as $1350 \mathrm{CE}$. This is considered to represent the oldest age for this advance, which is assigned to the LIA, as supported by a maximum ${ }^{14} \mathrm{C}$ age of $1450 \mathrm{CE}$, and $1480 \mathrm{CE}$ from six TCN samples from boulders on the outer moraine (Barnard et al., 2006). Two ${ }^{14} \mathrm{C}$ dates give a maximum age of $1633 \mathrm{CE}$ for the Yala II moraines (Shiraiwa and Watanabe, 1991), which are assigned to the LIA as the earlier moraines are deemed too old (Barnard et al., 2006). However, based on evidence for the timing of the LIA in the Everest region of Nepal, the Yala I and Yala II ages could represent the beginning and end of the LIA advance of Lirung Glacier, as the ages are similar to those produced for glaciers in the Khumbu Himal (Benedict, 1976; Fushimi, 1978; Muller, 1961), and the climatic regime is similar. TCN ages produced for two samples from moraines in the Mailun valley in the Ganesh Himal are only constrained to between $1000 \mathrm{CE}$ and the present day (Gayer et al., 2006). In the Annapurna region, seven TCN ages from the lateral moraines of Milarepa Glacier suggest an advance around $1530 \pm 60 \mathrm{CE}$ (Heimsath and McGlynn, 2008).

Northern India and Tibet. The Uttarakhand region of northern India includes the longest glacier in the Central Himalaya, Gangotri Glacier, and the well-studied Garhwal catchment. The foreland of Gangotri Glacier contains numerous small moraines that represent advances, locally named the Bhujbas Stage, dated using TCN to 1700-1800 CE (Barnard et al., 2004). TCN ages for moraines formed by Jaundhar and Bandarpunch Glaciers in the Tons valley gave $1400 \pm 200 \mathrm{CE}$ and $1700 \pm 100 \mathrm{CE}$ from two samples per moraine (Scherler et al., 2010). The central and western regions of Garhwal contain moraines from several glaciers including Gangotri Glacier that were assigned to the LIA using TCN dating. These results were combined with those published for other nearby moraines to assign a regional age from seven samples of $1600 \pm 100 \mathrm{CE}$ for the LIA in the Central Himalaya, which was preceded by periods of advance at $500 \pm 200 \mathrm{CE}$ and
$1300 \pm 100 \mathrm{CE}$ (Murari et al., 2014). A well-dated moraine of Naimon'anyi Glacier in the Gurla Mandhata region of southern Tibet has an age of 700-900 CE based on TCN dating of five samples and is assigned to the LIA (Owen et al., 2010).

\section{Western Himalaya and Karakoram}

In the Nun-Kun region of India, the most recent moraine formed by Tarangoz Glacier has an age of $1550 \pm 50 \mathrm{CE}$ from two TCN dates produced from moraine boulders (Lee et al., 2013). Aeolian sediment overlying an older moraine formed by Tarangoz Glacier was dated using one ${ }^{14} \mathrm{C}$ age to $345-541 \mathrm{CE}$, which represents a minimum age for the earlier advance of this glacier (Lee et al., 2013). Two ages produced using ${ }^{14} \mathrm{C}$ for moraines in the Karakoram for Minapin Glacier in Pakistan gave 1444-1649 CE and a maximum age of $1205 \mathrm{CE}$ assigned to an advance named Pasu 1, and evidence for a later advance named Pasu 2 (Derbyshire and Owen, 1997). Historical records of glacier advance in the Karakoram indicate that glacial maxima may have occurred later here than for those glaciers further east, at around 1900-1920 CE (Kick, 1989).

\section{Summary and interpretation of glacial geochronologies}

The 66 glacial landform ages presented here span the period from $0 \mathrm{CE}$ to the present day (Figure 4) and include two distinct sets of moraines at many sites. Two recent periods of advance were identified: a late-Holocene advance around 800-900 CE and a LIA advance around 1300-1600 CE. The moraines representing the two advances have different geometries and can be distinguished from each other visually. The late-Holocene advance is marked by low relief, laterally extensive moraines. These moraines created a barrier to the subsequent LIA advance, such that the LIA is marked by higher relief moraines formed directly within the older landforms by glaciers that thickened rather than expanded laterally as they gained mass (Hambrey et al., 2008). The identification of these two sets of moraines gives confidence to the geochronology for these glaciers, as where there are multiple ages they are in the correct morpho-stratigraphic order, and there is agreement between ages from the same moraine produced using different techniques. For example, the maximum age of $1205 \mathrm{CE}$ for the moraine of Pasu Glacier in the Karakoram is the same feature as it is also dated as 1444-1649 CE (Derbyshire and Owen, 1997), and the age of $1200 \pm 100$ CE moraine of Jaundhar Glacier in the Central Himalaya corresponds to the same feature that was dated to $1600 \pm 100 \mathrm{CE}$ using two further TCN samples (Scherler et al., 2010). In the Khumbu valley, two clear sets of recent moraines exist for several glaciers (Figure 5), with the outer moraines dated to around 900 CE (Owen et al., 2009).

The late-Holocene advance reached a peak around $900 \mathrm{CE}$ which was preceded by an earlier peak around $400 \mathrm{CE}$ (Figure 4b); these two peaks represent either a spatial variability in the timing of the late-Holocene advance across the range or a drawnout period of glacier advance and stillstand. The LIA advance occurred around 1300-1600 CE (Figure 4b). The latter part of the LIA appears to have been drawn out almost until the present day, either because of spatial variability in the timing of advance or because of ongoing moraine building during a period of stability before glacier mass loss became sustained in the 20th century. Therefore, the last advance of glaciers in the Himalaya occurred 400-700 years before the present day, representing the LIA maximum and active moraine building.

Comparing results produced using different dating methods shows a slight variation in the inferred timing between TCN $(n=28)$ and ${ }^{14} \mathrm{C}(n=37)$ ages. For the late-Holocene advances, ${ }^{14} \mathrm{C}$ ages gives peaks at 392 and $825 \mathrm{CE}$, while TCN ages gives peaks 
slightly later at 495 and $887 \mathrm{CE}$. The one age produced using OSL for Lhotse Glacier gives an age of $900 \pm 200 \mathrm{CE}$ (Richards et al., 2000), which agrees within uncertainty with both of the possible ages for the second late-Holocene peak. The offset between results from these geochronological techniques is in agreement with the general relationship between the sample collection methods, whereby most of the ${ }^{14} \mathrm{C}$ samples were collected from soils or organic material beneath moraines which would be older than the moraine or within moraines which would be older than the glacier maximum, whereas TCN samples were collected from boulders on moraine crests which would be expected to be contemporary to the last phase of moraine building (Figure 3). A similar offset occurs for the LIA advance, with ${ }^{14} \mathrm{C}$ giving a peak at $1422 \mathrm{CE}$ and TCN giving a peak at $1649 \mathrm{CE}$. If only those ages produced using all techniques and assigned a maximum confidence level of 3 (Table 1$)$ are considered $(n=35)$, then the three peaks in the moraine age distribution occur at 392, 887 and 1525 CE.

The 66 ages used to calculate the timing of the LIA are mostly taken from glaciers in the Central Himalaya, with the exception of eight glaciers in other Himalayan regions, such as Minapin Glacier in the Hunza valley in the Karakoram, Tarangoz Glacier in India in the Western Himalaya and Zelongnong Glacier in Tibet in the Eastern Himalaya. The LIA ages are collected from sites spanning latitudes of $27.8-36.5^{\circ} \mathrm{N}$, and terminus altitudes of $2300-5200 \mathrm{~m}$. Moraine ages do not appear to be influenced by either altitude $\left(R^{2}=0.07\right)$ (Figure $\left.4 \mathrm{~d}\right)$ or longitude $\left(R^{2}=0.11\right)$ (Figure 4f). Moraine ages appear to have a relationship to glacier latitude $\left(R^{2}=0.49\right)$, suggesting that advances generally occurred earlier at lower latitudes (Figure 4e). However, the apparent correlations between timing of advance and glacier location may be biased by the uneven spatial distribution of sites, whereby many samples were collected in the Everest region of Nepal or the Garhwal region of India.

The end of the LIA is difficult to define, particularly as debriscovered glaciers have undergone relatively little change in their extents such that glacier tongues still occupy their LIA moraines (Figures 5 and 6) (Rowan et al., 2015). Glacier recession is ongoing throughout the Himalaya, despite the observation of anomalous recent advances in the Karakoram (Kääb et al., 2012). However, the timing of LIA moraine formation indicated by the positively skewed distribution of moraine ages (Figure $4 b$ ) suggests that glaciers remained close to their LIA maxima until the end of the 19th Century (Figure 4a-c). Two glaciofluvial samples from the proglacial area of Gangotri Glacier in the Central Himalaya dated using TCN to 1370 and $1450 \mathrm{CE}$ represent deposits formed after the onset of glacier mass loss (Barnard et al., 2004). Supraglacial debris on Rongbuk Glacier dated using TCN to investigate the minimum likely age of the decline of debris transport offglacier demonstrate that sustained glacier recession occurred between 1300 and 2000 CE (Owen et al., 2009). A similar age from Milarepa's Glacier in India from $10 \mathrm{TCN}$ samples suggested that supraglacial debris was in situ since $1670 \pm 70 \mathrm{CE}$ (Heimsath and McGlynn, 2008).

\section{Late-Holocene palaeoclimate proxy records}

Palaeoclimate data for the last 2000 years have been produced from ice cores, speleothems, dendrochronology and lacustrine sediments in the Himalaya (Figure 2). To investigate the drivers of the late-Holocene and LIA advances identified from moraine ages, these palaeoclimate proxy records are summarised here and compared with the timing of glacier advances derived from moraine geochronologies (Figure 7).

\section{Ice cores}

Ice cores indicate the timing of past glacier accumulation at two high-altitude sites in the central Himalaya; Dasuopu Glacier in
Tibet directly north of the Langtang valley (Thompson et al., 2000) and East Rongbuk Glacier in the Everest region (Kaspari et al., 2007, 2008). Multiple ice cores were recovered from East Rongbuk Glacier at altitudes around or above $6500 \mathrm{~m}$. A $108-\mathrm{m}$ ice core spanning 1534-2001 CE showed that the mean glacier accumulation rate was $0.8 \mathrm{~m}$ ice equivalent per year between 1500 and $1600 \mathrm{CE}$, which decreased to $0.3 \mathrm{~m}$ ice equivalent per year around $1850 \mathrm{CE}$, then increased from 1880 to $1970 \mathrm{CE}$, and decreased again from 1970 to $2001 \mathrm{CE}$, likely controlled by monsoon precipitation (Kaspari et al., 2008). The East Rongbuk core indicates an abrupt southward shift in the South Asian monsoon around $1400 \mathrm{CE}$ driven by a reorganisation of Northern Hemisphere atmospheric circulation and resulting in a reduction in precipitation at the range crest (Kaspari et al., 2007). Three cores up to $160 \mathrm{~m}$ in length were recovered from Dasuopu Glacier at $7000-7200 \mathrm{~m}$, spanning from $1440 \mathrm{CE}$ to the present with an uncertainty of \pm 3 years and extrapolated to $1000 \mathrm{CE}$ with an uncertainty of \pm 5 years (Thompson et al., 2000). Decadal averaged snow accumulation from two of these cores was variable between 1400 and $1600 \mathrm{CE}$, giving values similar to those of $0.5-1.2 \mathrm{~m}$ water equivalent recorded from 1600 to $1817 \mathrm{CE}$. Glacier accumulation increased significantly to $1.0-1.7 \mathrm{~m}$ water equivalent between 1817 and $1880 \mathrm{CE}$, then gradually decreased after $1880 \mathrm{CE}$ to present-day values. Increased glacier accumulation was driven by increased monsoon intensity and not redistribution by ice flow (Kaspari et al., 2008). Since 1860 CE, air temperatures and atmospheric dust content in the cores have risen, consistent with accelerating industrialisation in India and Nepal (Thompson et al., 2000). The Dasuopu core records maximum accumulation from 1880 to $1890 \mathrm{CE}$, while the East Rongbuk core shows a minimum, and it is not known whether this is because of the altitudinal difference of $700 \mathrm{~m}$ between these sites or regional climatic controls (Kaspari et al., 2008).

\section{Speleothems}

Speleothems collected from caves in the foothills of the Central Himalaya indicate wet and cool conditions around 1500-1850 $\mathrm{CE}$, although hydrological conditions were spatially variable (Denniston et al., 2000; Kotlia et al., 2012; Liang et al., 2015). A speleothem collected from Chulerasim cave $(1524 \mathrm{~m})$ spanning 1590-2006 CE indicates a wet phase followed by a somewhat drier climate after 1850 CE (Kotlia et al., 2012). A nearby site $40 \mathrm{~km}$ to the north at Sainji Cave $(1478 \mathrm{~m})$ confirmed increased precipitation between 1450 and $1700 \mathrm{CE}$ probably resulting from increased Westerly rather than monsoon precipitation (Kotlia et al., 2015). Another speleothem collected from Siddha Baba cave in the Pokhara valley in Nepal $(\sim 2000 \mathrm{~m})$ indicated reduced monsoon precipitation between 2.3 and 1.5 ka followed by moist, cold conditions between 1550 and $1640 \mathrm{CE}$ (Denniston et al., 2000). A speleothem from Panigarh Cave in Western Uttar Pradesh in India $(1520 \mathrm{~m})$ indicated cooler and wetter conditions between 1489-1889 CE and 1450-1820 CE (Liang et al., 2015), although the climate was warmer and drier both before and after this period, because of weakening of the South Asian monsoon (Liang et al., 2015).

\section{Dendrochronology}

Several studies of recent glacier change have been carried out in southeastern Tibet near Mt Gyala Peri in the upper Brahmaputra catchment using analyses of tree rings (e.g. Loibl et al., 2015). Although these sites are about $30 \mathrm{~km}$ to the north of the boundary of the Eastern Himalaya region defined by the Brahmaputra river, their results are valuable and relevant to understanding the climate of the Eastern Himalaya and so included here. Trees around Mt Gyala Peri (3780-4370m) gave a chronology for moraines spanning 1630-1993 CE, indicating that the minimum ages for 
(a)

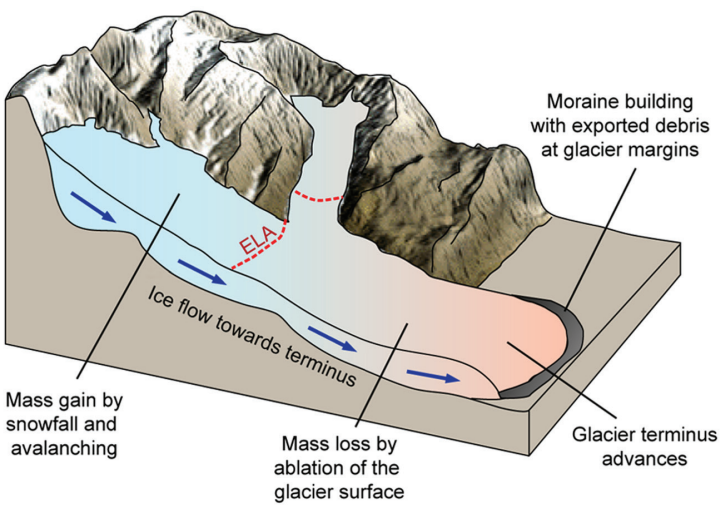

(c)

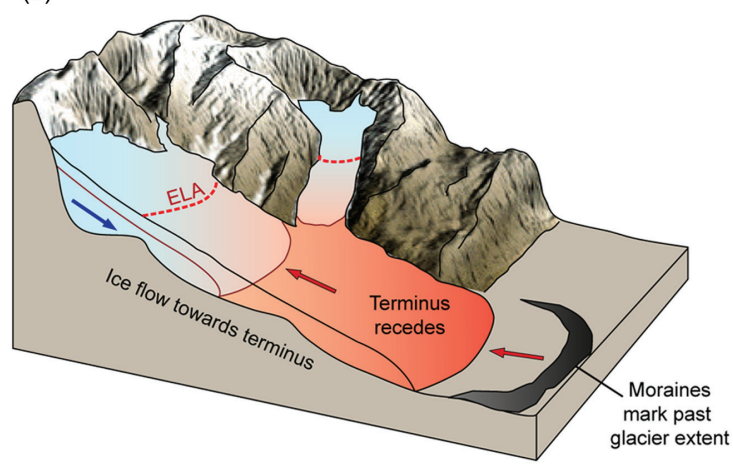

(b)

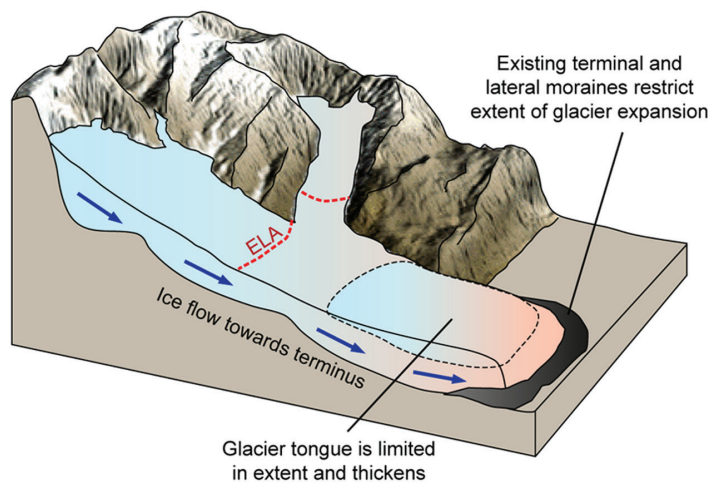

(d)

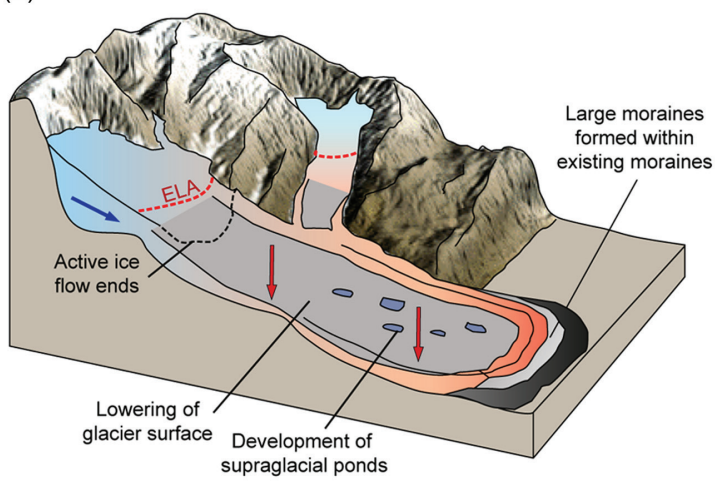

Figure 6. The mechanisms of glacier evolution and moraine formation by clean-ice and debris-covered glaciers during advance and recession: (a) glacier during advance, (b) glacier during advance restricted by existing moraine, (c) clean-ice glacier during recession and (d) debris-covered glacier during mass loss (recession). ELA: Equilibrium Line Altitude.

moraine formation by two glaciers were $1760-1780 \mathrm{CE}$, while a third glacier advanced around 1580,1800 and 1870 CE (Bräuning, 2006). The age of the oldest living tree on the lateral moraine of Xinpu Glacier was calculated as $1662 \mathrm{CE}$, suggesting that moraine formation was complete by this time (Loibl et al., 2015). In the Eastern Himalaya, trees sampled at Ura and Dhur in central Bhutan (3096 and $3440 \mathrm{~m}$ ) showed that the most pronounced cold periods of the last 600 years were from 1431-1433 CE and 1533$1535 \mathrm{CE}$, and the coldest period was 1690-1710 CE (Krusic et al., 2015). In the Central Himalaya, trees in the Macha Khola valley in Nepal indicate cold periods at 1815-1825 CE and 19001910 CE (Zech et al., 2003). Reconstruction of Spring temperatures between 1390 and $1987 \mathrm{CE}$ from trees near Gangotri Glacier in Uttar Pradesh in India did not indicate any centennial cold excursions, suggesting that the LIA was a minor event in terms of change in Spring temperatures, and that the period 1600-1700 CE was generally warm (Yadav et al., 1999). In the Western Himalaya, temperatures inferred from tree rings in Lahaul-Spiti (3200$3600 \mathrm{~m}$ ) showed warm summer temperatures between 1000-1100 $\mathrm{CE}$ and 1400-1500 CE. These warm periods were followed by decreasing summer temperatures after $1500 \mathrm{CE}$, with the 1700 $1900 \mathrm{CE}$ being the coldest interval of the last millennium (Yadav et al., 2011).

\section{Lacustrine sediments}

Sediment cores taken from two isolated lakes above $5000 \mathrm{~m}$ altitude in the Khumbu Glacier valley analysed using diatom populations indicated a cool but variable climate between 300 and 900 CE followed by climatic amelioration between 900 and $1400 \mathrm{CE}$, then a colder period between 1400 and 1900 CE (Lami et al., 2010). In the Western Himalaya, analyses of peat-lake sediment from small lake sited on a moraine from the Chandra valley in India indicated prominent cold-dry event at 1303-1609 CE (Rawat et al., 2015). On the Tibetan Plateau, analysis of the timing of lake formation and drying and the southward migration of trees and grassland indicate generally wetter-than-present conditions during the LIA, followed by drying during the 20th Century greater than at any time since 1200 CE (Putnam et al., 2016).

\section{Discussion}

\section{Inferring the drivers of glacier change from} palaeoclimate records

Observations and dating of recent moraines in the Himalaya indicate that for those glaciers with geochronological data, at least one and in some cases two advances have occurred since $0 \mathrm{CE}$. The late-Holocene advance occurred around $900 \mathrm{CE}$ and may have occurred as two phases of advance with an earlier peak around $400 \mathrm{CE}$, or may represent one longer period of glacier maximum from 400 to $900 \mathrm{CE}$ with few data placing moraine formation around 600-700 CE. The LIA advance in the Himalaya is more clearly constrained from the available geochronological data as a peak in moraine building around 1300-1600 CE. The drivers of glacier advance can be inferred by comparing the timing and distribution of moraine building with local and regional changes in climate over the same period observed from palaeoclimate proxy records. LIA glacier advance appears to have occurred 100 years before lowest mean annual Northern Hemisphere air temperatures (Figure 7), during a period of variable climate that led to weakening of the monsoon around $1400 \mathrm{CE}$, bringing increased winter precipitation into the Himalaya (Liang et al., 2015; Murari et al., 2014). Tree rings suggest that regional climate varied rapidly from $1000 \mathrm{CE}$, with generally cold conditions observed during 1300-1500 CE and 1800-1900 CE across the Eastern and Central Himalaya (Bräuning, 2006; Krusic et al., 2015; Loibl et al., 2015; Zech et al., 2003). 


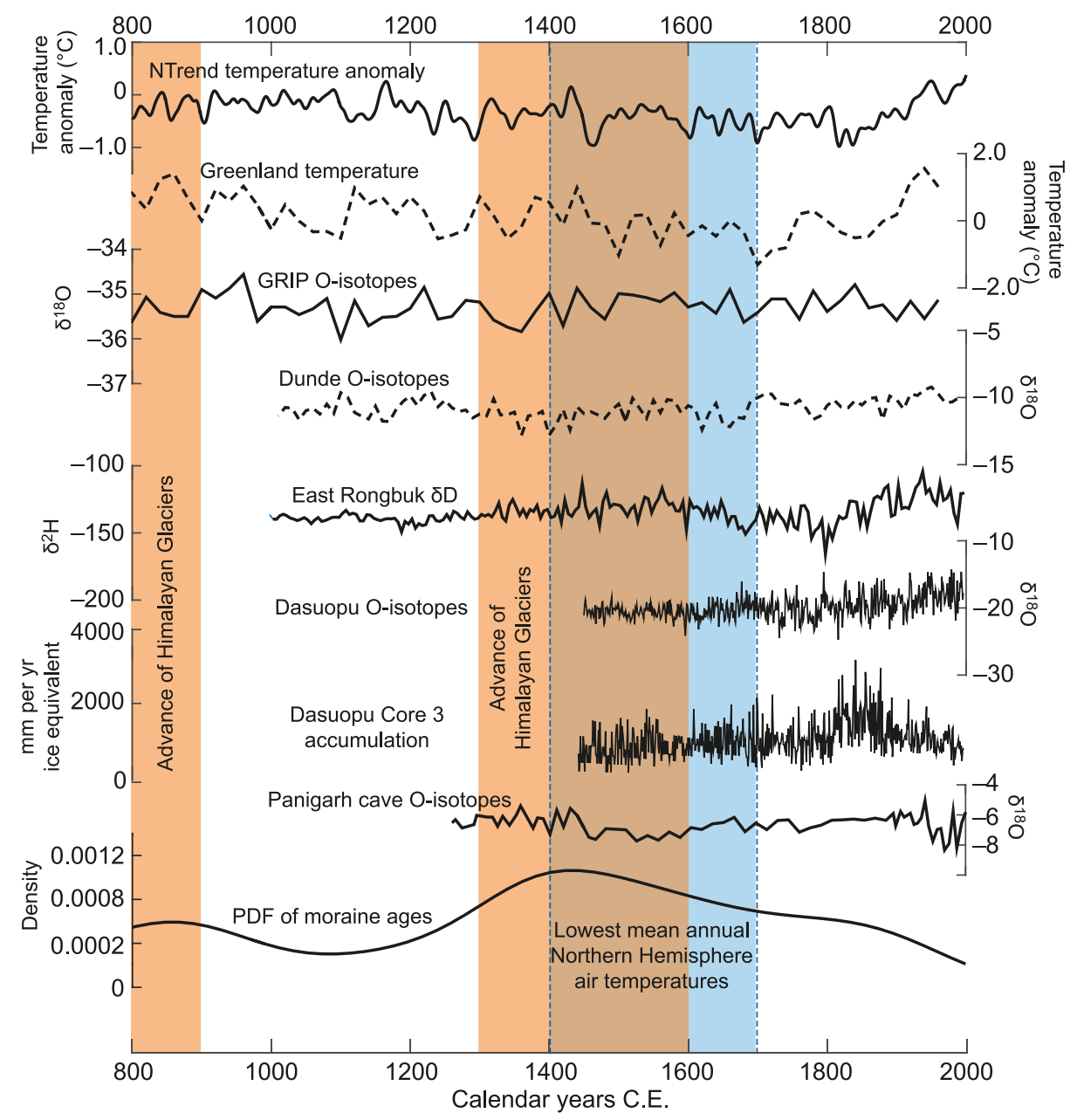

Figure 7. Palaeoclimate proxy data for the Himalaya from 800 to 2000 CE showing Northern Hemisphere temperature anomaly from tree ring data (NTrend;Wilson et al., 2016), Greenland temperature anomaly (Vinther et al., 2009), Greenland GRIP ice core Oxygen isotopes (Vinther et al., 2009), Himalayan ice core Oxygen isotopes from Dunde (Thompson et al., 2003), East Rongbuk (Kaspari et al., 2007) and Dasuopu Glaciers (Thompson et al., 2003), glacier accumulation from Dasuopu Glacier (Thompson et al., 2003), speleothem Oxygen isotopes from Panigarh Cave in India (Liang et al., 20I5) and the distribution of all the moraine ages calculated in this study.

Glacier change can be directly related to climate change by considering the impact of variations in mean annual air temperatures and precipitation amount and distribution on net mass balance. However, the relationships describing the response of glaciers to climate change are not well constrained for the Himalaya, and particularly difficult to infer where thick debris layers on the surface of many glaciers also affect mass balance (Rowan et al., 2015). ELA is generally used to link glacier mass balance to regional temperature. ELA position and change in ELA may be difficult to determine for mountain glaciers that are strongly influenced by topography, particularly when they are debris-covered, although in many cases, the maximum elevation of lateral moraines can be used to estimate ELA (Benn and Lehmkuhl, 2000; Owen and Benn, 2005). Glacier-climate model simulations of ELA change from the LIA to present-day for two debris-free glaciers in the Eastern Himalaya demonstrated that sustaining these glaciers at their LIA limits required a decrease in mean annual air temperature of $1-2.5^{\circ} \mathrm{C}$ and an increase in precipitation of 8-25\% compared with the period 2000-2012 CE (Huintjes et al., 2016). The simulated conditions for LIA ELA change are greater than the change in Northern Hemisphere temperature inferred from tree rings of $-0.5^{\circ} \mathrm{C}$ (Wilson et al., 2016), suggesting that LIA cooling was enhanced in the Himalaya at high altitudes, and that increased winter precipitation during the LIA because of monsoon weakening also played a role in driving glacier advance (Liang et al., 2015).
Ice core records from East Rongbuk and Dasuopu Glaciers show that glacier accumulation was variable through the lateHolocene and dependent on monsoon intensity, with high accumulation between 1400 and $1600 \mathrm{CE}$, that reduced over time in the Everest region while increasing further west (Kaspari et al., 2007; Thompson et al., 2000). However, both of the sampled glaciers flow north from the range crest and are likely to experience slightly drier climate during periods of cooling as the monsoon shifted southward. These high-altitude ice cores and speleothems collected at low latitudes on the south side of the range indicate increased precipitation from $1400 \mathrm{CE}$ as the monsoon moved southward, accompanied by cooler temperatures and an increase in Westerly winter precipitation (Kotlia et al., 2012, 2015; Liang et al., 2015). The late-Holocene and LIA glacier advances in the Garhwal valley in the Central Himalaya are out-of-phase with hemispheric temperature records, suggesting that these stages resulted from variations in the Westerlies (Murari et al., 2014). The LIA occurred slightly later in the Western Himalaya where the influence of the Westerlies is greater than further east. These glacier advances occurred between 1700 and 1900 CE (Yadav et al., 2011), although there is evidence from lacustrine sediments of cold conditions lasting for several centuries from $1300 \mathrm{CE}$ (Rawat et al., 2015). Precipitation delivery by large regional weather systems therefore appears to be a key driver of glacier accumulation. Variability in the distribution of winter precipitation by the monsoon and Westerly weather systems occurs in 
response to hemispheric temperature change, implying that glacier advance in the Himalaya does not occur solely in response to cooling temperatures but is enhanced by the regional variability in precipitation distribution and timing that results from changing air temperatures across high topography.

\section{Dating and interpretation of Holocene moraines}

Early observations of the condition of glaciers in the Himalaya and their recent moraines in the absence of geochronological data led researchers to correlate the advances of Himalayan glaciers to those of European glaciers (Grove, 2004; Iwata, 1976). Historical accounts between 1850 and $1920 \mathrm{CE}$ of glaciers close to their LIA extents, as indicated by lateral and terminal moraine positions, may have been misinterpreted as evidence for LIA maxima (Grove, 2004) when instead these glaciers have only undergone minor changes in area between their last advance around $1500 \mathrm{CE}$ and the present day. A further limitation of these historical records is that the observation of glacier extents in the Himalaya only began around $1850 \mathrm{CE}$, so no records existed of an earlier onset of advance until the advent of numerical dating methods. For example, the advance of Kyuwo Glacier in Nepal around 1500 CE identified from a ${ }^{14} \mathrm{C}$ age by Fushimi (1978) is unlikely to be the late-Holocene advance to which it was assigned in the absence of other geochronological data, and more likely to represent the LIA advance. Fushimi (1978) also identified another moraine at the same site as older based on its stratigraphic position, which he dated to 658-1014 CE and assigned the Pheriche (LGM) advance. However, the correlation of this advance of Kyuwo Glacier with the LGM moraines formed by larger glaciers in the Khumbu Himal is based on the interpretation of stratigraphic position, where at least three sets of moraines representing distinct advances between the LGM and LIA occur close to the terminus of the small glacier (Finkel et al., 2003). TCN ages for the Pheriche advance of neighbouring Khumbu and Lhotse Glaciers assigned the LGM to around 21 ka (Owen et al., 2009). Fushimi's ${ }^{14} \mathrm{C}$ sample was collected from the late-Holocene rather than LGM moraine as these features were not distinguished as separate landforms.

The development of numerical isotopic dating methods $\left({ }^{14} \mathrm{C}\right.$, TCN and OSL) resolved some confusion resulting from attempts to correlate glacier advances in the Himalaya with each other and with those in Europe (e.g. Iwata, 1976). Numerical ages allow the comparison of the timing of moraine formation where these cannot be directly correlated in the field, and remove some of the uncertainties associated with these correlations. Advances in geochronological techniques that allow the rapid and economical production of multiple ages for individual moraines will greatly increase the scope of these correlations, particularly if initial data can be collected in the field to guide the sampling protocol (e.g. Stone et al., 2015). However, individual glaciers can respond in a different manner to the same change in climate as neighbouring glaciers in the same catchment. As such, making correlations between moraines formed by glaciers of very different sizes is challenging in the absence of geochronological data, as described above for Kyuwo and Khumbu Glaciers, and as evidenced by different but contemporaneous moraines produced by LIA advances in southeastern Tibet (Loibl et al., 2015).

Correlation of undated moraines with those for which numerical geochronological data are available, for example, between Nepal and Bhutan (Iwata et al., 2002) or between India and Pakistan (Owen et al., 1996), are tempting but unlikely to be reliable. High spatial variability in glacier change, resulting from variations in climatic regime and geomorphological setting (Kirkbride and Winkler, 2012), complicates comparisons of the timing and extent of glacier advance between regions of the Himalaya. Collecting multiple samples for dating from each moraine allows more robust ages to be generated that reflect the possibility of an age distribution influenced by surface processes and measurement uncertainties (Applegate et al., 2010). The use of multiple techniques to date moraines from a set of glaciers rather than one individual glacier means that results are likely to be more robust as uncertainties associated with the application of dating techniques to a small number of samples are reduced. The abundance of geochronological and geomorphological data from the Everest region also reduces the likelihood of uncertainties resulting from only considering the behaviour of one glacier that may not represent the behaviour of a set of glaciers in response to regional climate change.

\section{Conclusion}

Geochronological data from recent moraines formed by glaciers in the Himalaya indicate that these glaciers advanced during the lateHolocene around $900 \mathrm{CE}$ (number of ages $(n)=41$ ) and during the Little Ice Age (LIA) between 1300 and $1600 \mathrm{CE}(n=25)$ (Table 1). The timing and duration of the LIA in the Himalaya indicated by the distribution of moraine ages suggests that glacier maxima, inferred from periods of moraine building, commenced around $1300 \mathrm{CE}$, slightly earlier than the period of sustained Northern Hemisphere cooling between 1400 and $1700 \mathrm{CE}$. The end of the LIA is less clearly defined. Some moraine ages place these features in the early 20th Century suggesting stable glacier margins and ongoing moraine building until this time. Many large debriscovered Himalayan glaciers have remained close to their LIA limits until the present day, although these glaciers have lost large volumes of ice during the 20th Century by surface lowering rather than terminus recession. The onset of the LIA occurred during a period of variable climate across the Himalaya with cooling temperatures from $1300 \mathrm{CE}$. Reduced regional and Northern Hemisphere air temperatures from 1300 to $1400 \mathrm{CE}$ resulted in a southward shift in the Indian summer monsoon and increased Westerly precipitation that led to greater snowfall and glacier accumulation at high altitudes. Combined with cold Northern Hemisphere temperatures, this increase in winter precipitation contributed to and may have initiated glacier expansion during the LIA.

The timing of the last two advances of glaciers in the Himalaya are calculated from 66 ages for the moraines formed by 24 glaciers using 138 geochronological samples at altitudes ranging from 2000 to $5200 \mathrm{~m}$ a.s.l. and mostly collected from sites in the Central Himalaya $\left(27.8-31.1^{\circ} \mathrm{N}\right)$. The Himalaya occupy a large geographical area and there are relatively few ages for LIA moraines across the range, particularly in the Eastern and Western Himalaya. The available data indicate that, at least in the Central Himalaya region, glacier advance during the late-Holocene and LIA was widespread. The timing of the LIA varied across the Central Himalaya because of the influence of the Westerlies and monsoon. Advances occurred slightly earlier at lower latitudes, and later in the western section of the range. Glacier and catchment characteristics should be considered when comparing the timing and magnitude of advances, as factors such as glacier size, hypsometry, aspect and dynamics are likely to influence their response to climate change. The production of greater numbers of ages and collecting multiple samples for dating from each moraine are important to separate variability resulting from geomorphological processes from the climatic drivers of glacier advance. Expanding the range of sampled sites across the Himalaya and sampling multiple adjacent glaciers with different characteristics could resolve these uncertainties and better constrain the timing and drivers of the last advance of glaciers in the Himalaya.

\section{Acknowledgements}

A Rowan is supported by a Vice-Chancellor's Fellowship from the University of Sheffield. Stephen Livingstone and Duncan Quincey are thanked for their helpful comments on an earlier 
version of this manuscript. Fuyuan Liang is thanked for providing Panigarh cave Oxygen isotope data. Two anonymous reviewers are thanked for providing constructive reviews of this manuscript.

\section{Funding}

The author(s) received no financial support for the research, authorship and/or publication of this article.

\section{References}

Applegate PJ, Urban NM and Laabs B (2010) Modeling the statistical distributions of cosmogenic exposure dates from moraines. Geoscientific Model Development 3: 293-307.

Barnard PL, Owen LA and Finkel RC (2004) Style and timing of glacial and paraglacial sedimentation in a monsoon-influenced high Himalayan environment, the upper Bhagirathi Valley, Garhwal Himalaya. Sedimentary Geology 165(3-4): 199-221.

Barnard PL, Owen LA, Finkel RC et al. (2006) Landscape response to deglaciation in a high relief, monsoon-influenced alpine environment, Langtang Himal, Nepal. Quaternary Science Reviews 25(17-18): 2162-2176.

Benedict JB (1976) Khumbu Glacier series, Nepal. Radiocarbon 18(2): 117-178.

Benn DI and Lehmkuhl F (2000) Mass balance and equilibriumline altitudes of glaciers in high-mountain environments. Quaternary International 65: 15-29.

Benn DI, Bolch T, Hands K et al. (2012) Response of debris-covered glaciers in the Mount Everest region to recent warming, and implications for outburst flood hazards. Earth-Science Reviews 114: 156-174.

Bolch T, Kulkarni A, Kääb A et al. (2012) The state and fate of Himalayan glaciers. Science 336(6079): 310-314.

Bräuning A (2006) Tree-ring evidence of 'Little Ice Age' glacier advances in southern Tibet. The Holocene 16(3): 369-380.

Denniston RF, González LA, Asmerom Y et al. (2000) Speleothem evidence for changes in Indian summer monsoon precipitation over the last $\sim 2300$ years. Quaternary Research 53(2): 196-202.

Derbyshire E and Owen LA (1997) Quaternary glacial history of the Karakoram Mountains and northwest Himalayas: A review. Quaternary International 38: 85-102.

Derbyshire E, Jijun L, Perrot FA et al. (1984) Quaternary glacial history of the Hunza valley Karakoram Mountains, Pakistan. In: Miller K (ed.) International Karakoram Project. Cambridge University Press, pp. 456-495.

Dortch JM, Owen LA and Caffee MW (2013) Timing and climatic drivers for glaciation across semi-arid western HimalayanTibetan orogen. Quaternary Science Reviews 78: 188-208.

Finkel RC, Owen LA, Barnard PL et al. (2003) Beryllium-10 dating of Mount Everest moraines indicates a strong monsoon influence and glacial synchroneity throughout the Himalaya. Geology 31(6): 561-564.

Fushimi H (1978) Glaciations in the Khumbu Himal (2): Glaciological Expedition of Nepal, Contribution No. 57. Seppyo 40: $71-77$.

Gayer E, Lave J, Pik R et al. (2006) Monsoonal forcing of Holocene glacier fluctuations in Ganesh Himal (Central Nepal) constrained by cosmogenic ${ }^{3} \mathrm{He}$ exposure ages of garnets. Earth and Planetary Science Letters 252(3-4): 275-288.

GLIMS, National Snow and Ice Data Center (2005) GLIMS Glacier Database (updated 2012) (Himalaya). Boulder, CO: National Snow and Ice Data Center.

Grove JM (2004) The Little Ice Age: Ancient and Modern. 2nd Edition. London: Routledge.

Hambrey MJ, Quincey DJ, Glasser NF et al. (2008) Sedimentological, geomorphological and dynamic context of debrismantled glaciers, Mount Everest (Sagarmatha) region, Nepal. Quaternary Science Reviews 27(25-26): 2361-2389.
Hedrick KA, Seong YB, Owen LA et al. (2011) Towards defining the transition in style and timing of Quaternary glaciation between the monsoon-influenced Greater Himalaya and the semi-arid Transhimalaya of Northern India. Quaternary International 236(1-2): 21-33.

Heimsath AM and McGlynn R (2008) Quantifying periglacial erosion in the Nepal high Himalaya. Geomorphology 97(12): 5-23.

Heyman J, Applegate PJ, Blomdin R et al. (2016) Boulder height - Exposure age relationships from a global glacial ${ }^{10} \mathrm{Be}$ compilation. Quaternary Geochronology 34: 1-11.

Holzhauser H, Magny MJ and Zumbühl HJ (2005) Glacier and lake-level variations in west-central Europe over the last 3500 years. The Holocene 15(6): 789-801.

Huintjes E, Loibl D, Lehmkuhl F et al. (2016) A modelling approach to reconstruct Little Ice Age climate from remotesensing glacier observations in southeastern Tibet. Annals of Glaciology 57(71): 359-370.

Iwata S (1976) Late Pleistocene and Holocene Moraines in the Sagarmatha (Everest) Region, Khumbu Himal: Glaciological Expedition to Nepal, Contribution No. 23. Seppyo 38: 109-114.

Iwata S, Narama C and Karma (2002) Three Holocene and late Pleistocene glacial stages inferred from moraines in the Lingshi and Thanza village areas, Bhutan. Quaternary International 97: 69-78.

Kääb A, Berthier E, Nuth C et al. (2012) Contrasting patterns of early twenty-first-century glacier mass change in the Himalayas. Nature 488(7412): 495-498.

Kaspari S, Hooke R and Mayewski PA (2008) Snow accumulation rate on Qomolangma (Mount Everest), Himalaya: Synchroneity with sites across the Tibetan Plateau on 50-100 year timescales. Journal of Glaciology 54: 343-352.

Kaspari S, Mayewski P, Kang S et al. (2007) Reduction in northward incursions of the South Asian monsoon since 1400 AD inferred from a Mt. Everest ice core. Geophysical Research Letters 34(16): L16701.

Kayastha RB and Harrison SP (2008) Changes of the equilibriumline altitude since the Little Ice Age in the Nepalese Himalaya. Annals of Glaciology 48(1): 93-99.

Kick W (1989) The decline of the last Little Ice Age in High Asia compared with that in the Alps. In: Oerlemans J (ed.) Glacier Fluctuations and Climatic Change. Dordrecht: Springer, pp. 129-142.

Kirkbride MP and Winkler S (2012) Correlation of Late Quaternary moraines: Impact of climate variability, glacier response, and chronological resolution. Quaternary Science Reviews 46: 1-29.

Kotlia BS, Ahmad SM, Zhao J-X et al. (2012) Climatic fluctuations during the LIA and post-LIA in the Kumaun Lesser Himalaya, India: Evidence from a 400 y old stalagmite record. Quaternary International 304: 183-192.

Kotlia BS, Singh AK, Joshi LM et al. (2015) Precipitation variability in the Indian Central Himalaya during last ca. 4,000 years inferred from a speleothem record: Impact of Indian Summer Monsoon (ISM) and Westerlies. Quaternary International 371: 244-253.

Krusic PJ, Cook ER, Dukpa D et al. (2015) Six hundred thirtyeight years of summer temperature variability over the Bhutanese Himalaya. Geophysical Research Letters 42: 2988-2994.

Lami A, Marchetto A, Musazzi S et al. (2010) Chemical and biological response of two small lakes in the Khumbu Valley, Himalayas (Nepal) to short-term variability and climatic change as detected by long-term monitoring and paleolimnological methods. Hydrobiologia 648(1): 189-205.

Larsen DJ, Miller GH and Geirsdottir A (2013) Asynchronous Little Ice Age glacier fluctuations in Iceland and European 
Alps linked to shifts in subpolar North Atlantic circulation. Earth and Planetary Science Letters 380: 52-59.

Lee SY, Seong YB, Owen LA et al. (2013) Late Quaternary glaciation in the Nun-Kun massif, northwestern India. Boreas 43(1): 67-89.

Lee SY, Seong YB, Owen LA et al. (2014) Late Quaternary glaciation in the Nun-Kun massif, northwestern India. Boreas 43(1): 67-89.

Liang F, Brook GA, Kotlia BS et al. (2015) Panigarh cave stalagmite evidence of climate change in the Indian Central Himalaya since AD 1256: Monsoon breaks and winter southern jet depressions. Quaternary Science Reviews 124: 145-161.

Loibl D, Hochreuther P, Schulte P et al. (2015) Toward a late Holocene glacial chronology for the eastern Nyainqêntanglha Range, southeastern Tibet. Quaternary Science Reviews 107: 243-259.

Lorrey A, Fauchereau N, Stanton C et al. (2013) The Little Ice Age climate of New Zealand reconstructed from Southern Alps cirque glaciers: A synoptic type approach. Climate Dynamics 42(11-12): 3039-3060.

Luckman BH (2000) The Little Ice Age in the Canadian Rockies. Geomorphology 32: 357-384.

Mann ME, Zhang Z and Rutherford S (2009) Global signatures and dynamical origins of the Little Ice Age and Medieval Climate Anomaly. Science 326(5957): 1253-1256.

Mayewski PA and Jeschke PA (1979) Himalayan and trans-Himalayan glacier fluctuations since $\mathrm{AD}$ 1812. Arctic and Alpine Research 11(3): 267-287.

Meyer MC, Hofmann CC, Gemmell AMD et al. (2009) Holocene glacier fluctuations and migration of Neolithic yak pastoralists into the high valleys of northwest Bhutan. Quaternary Science Reviews 28(13-14): 1217-1237.

Muller F (1961) Khumbu moraine series, Nepal. Radiocarbon 3: 16.

Murari MK, Owen LA, Dortch JM et al. (2014) Timing and climatic drivers for glaciation across monsoon-influenced regions of the Himalayan-Tibetan orogen. Quaternary Science Reviews 88: 159-182.

Oerlemans J, Anderson B, Hubbard A et al. (1998) Modelling the response of glaciers to climate warming. Climate Dynamics 14(4): 267-274.

Owen LA and Benn DI (2005) Equilibrium-line altitudes of the Last Glacial Maximum for the Himalaya and Tibet: An assessment and evaluation of results. Quaternary International 138-139: 55-78.

Owen LA and Dortch JM (2014) Nature and timing of Quaternary glaciation in the Himalayan-Tibetan orogen. Quaternary Science Reviews 88: 14-54.

Owen LA, Derbyshire E, Richardson S et al. (1996) The Quaternary glacial history of the Lahul Himalaya, northern India. Journal of Quaternary Science 11(1): 25-42.

Owen LA, Robinson R, Benn DI et al. (2009) Quaternary glaciation of Mount Everest. Quaternary Science Reviews 28(1516): 1412-1433.

Owen LA, Yi C, Finkel RC et al. (2010) Quaternary glaciation of Gurla Mandhata (Naimon'anyi). Quaternary Science Reviews 29(15-16): 1817-1830.

Putnam AE, Putnam DE, Andreu-Hayles L et al. (2016) Little Ice Age wetting of interior Asian deserts and the rise of the Mongol Empire. Quaternary Science Reviews 131(Part A): $33-50$.

Rawat S, Gupta AK, Sangode SJ et al. (2015) Late PleistoceneHolocene vegetation and Indian summer monsoon record from the Lahaul, Northwest Himalaya, India. Quaternary Science Reviews 114: 167-181.
Reimer PJ, Bard E, Bayliss A et al. (2013) IntCal13 and Marine13 radiocarbon age calibration curves $0-50,000$ years cal BP. Radiocarbon 55(4): 1869-1887.

Richards B, Benn D and Owen L (2000) Timing of late Quaternary glaciations south of Mount Everest in the Khumbu Himal, Nepal. Geological Society of America Bulletin 112: 1621-1632.

Röthlisberger F and Geyh M (1986) Glacier variations in Himalayas and Karakorum. Journal of Glaciology and Geocryology 4: 237-249.

Rowan AV, Egholm DL, Quincey DJ et al. (2015) Modelling the feedbacks between mass balance, ice flow and debris transport to predict the response to climate change of debris-covered glaciers in the Himalaya. Earth and Planetary Science Letters 430: 427-438.

Scherler D, Bookhagen B, Strecker MR et al. (2010) Timing and extent of late Quaternary glaciation in the western Himalaya constrained by ${ }^{10} \mathrm{Be}$ moraine dating in Garhwal, India. Quaternary Science Reviews 29(7-8): 815-831.

Schimmelpfennig I, Schaefer JM, Akcar N et al. (2012) Holocene glacier culminations in the Western Alps and their hemispheric relevance. Geology 40(10): 891-894.

Schimmelpfennig I, Schaefer JM, Akçar N et al. (2014) A chronology of Holocene and Little Ice Age glacier culminations of the Steingletscher, Central Alps, Switzerland, based on high-sensitivity beryllium-10 moraine dating. Earth and Planetary Science Letters 393: 220-230.

Shiraiwa T and Watanabe T (1991) Late Quaternary glacial fluctuations in the Langtang valley, Nepal Himalaya, reconstructed by relative dating methods. Arctic and Alpine Research 23(4): 404-416.

Stone AEC, Bateman MD and Thomas DSG (2015) Rapid age assessment in the Namib Sand Sea using a portable luminescence reader. Quaternary Geochronology 30(Part B): 134-140.

Thompson LG, Mosley-Thompson E, Davis ME et al. (2003) Tropical glacier and ice core evidence of climate change on annual to millennial time scales. Climatic Change 59: $137-155$.

Thompson LG, Yao T, Mosley-Thompson E et al. (2000) A highresolution millennial record of the South Asian monsoon from Himalayan ice cores. Science 289(5486): 1916-1919.

Vinther BM, Buchardt SL, Clausen HB et al. (2009) Holocene thinning of the Greenland ice sheet. Nature 461(7262): $385-388$

Wilson R, Anchukaitis K, Briffa KR et al. (2016) Last millennium northern hemisphere summer temperatures from tree rings: Part I: The long term context. Quaternary Science Reviews 134: 1-18.

Yadav RR, Braeuning A and Singh J (2011) Tree ring inferred summer temperature variations over the last millennium in western Himalaya, India. Climate Dynamics 36(7-8): 15451554

Yadav RR, Park W-K and Bhattacharyya A (1999) Spring-temperature variations in western Himalaya, India, as reconstructed from tree-rings: AD1390-1987. The Holocene 9(1): 85-90.

Zech R, Zech M, Kubik PW et al. (2009) Deglaciation and landscape history around Annapurna, Nepal, based on ${ }^{10} \mathrm{Be}$ surface exposure dating. Quaternary Science Reviews 28(1112): 1106-1118.

Zech W, Glaser B, Abramowski U et al. (2003) Reconstruction of the Late Quaternary Glaciation of the Macha Khola valley (Gorkha Himal, Nepal) using relative and numerical $\left({ }^{14} \mathrm{C}\right.$, ${ }^{10} \mathrm{Be}$, dendrochronology) dating techniques. Quaternary Science Reviews 22(21-22): 2253-2265. 